\title{
RESISTÊNCIA DE CISTO DE GIARDIA SPP A DESINFECÇÃO POR PEROXIDAÇÃO ASSISTIDA POR RADIAÇÃO UV .
}

\author{
Claudio V. Neto*, Lays Leonel Paulino, Jerusa Schneider.
}

\section{Resumo}

O presente trabalho teve como objetivo avaliar a eficiência da combinação entre a radiação ultravioleta e o peróxido de hidrogênio como agente desinfetante, o chamado processo de oxidação avançada. Para tanto, empregou-se os métodos de reação de imunofluorescência direta (RID) e de microscopia eletrônica de varredura (MEV) a fim de verificar a integridade dos cistos de Giardia spp. empregados no ensaio. Constatou-se danos a parede celular em todos os ensaios e média de $79 \%$ de inativação dos cistos, o que corrobora a eficiência desse método de desinfeção.

\section{Palavras-chave:}

Processos oxidativos avançados, tratamento de efluentes, giardia.

\section{Introdução}

Com a crescente demanda sobre os recursos hídricos e tento em vista o aumento da qualidade da água potável disponível, processos de desinfecção estão cada vez mais em pauta. Os processos de oxidação avançada (POA) constituem uma alternativa aos meios convencionais de tratamento, como a cloração, uma vez que os radicais hidroxila dispõe de elevado potencial de oxidação e baixa seletividade ${ }^{1}$. Ademais, na presença da radiação ultravioleta (UV) - que também possuí caráter oxidante - a reação de quebra do peróxido de hidrogênio $\left(\mathrm{H}_{2} \mathrm{O}_{2}\right)$ em íons hidroxila acontece com um rendimento próximo de $100 \%{ }^{1}$.

Tendo em vista o que foi exposto, o presente projeto procurou avaliar a eficiência da combinação do $\mathrm{H}_{2} \mathrm{O}_{2}$ com a radiação ultravioleta emitida por lâmpadas LED (Light Emitting Diode) (UV-LED) no que concerne a inativação de cistos de Giardia spp. Realizou-se a visualização da alteração da forma e luminescência dos cistos expostos aos desinfetantes, por meio dos métodos de imunofluorescência direta (RID) e de microscopia eletrônica de varredura (MEV).

\section{Resultados e Discussão}

O efluente empregado nos ensaios era originário da Estação de Tratamento de Efluentes do distrito de Barão Geraldo, Campinas (SP). A partir dos resultados obtidos através do projeto de doutorado desenvolvido na Pósgraduação da Faculdade de Engenharia Civil, Arquitetura e Urbanismo da UNICAMP, determinou-se a melhor concentração de $\mathrm{H}_{2} \mathrm{O}_{2}$ bem como o tempo de exposição e comprimentos de ondas ideias para o UV-LED.

Nota-se que na Figura 1A e 1B que a delimitação entre 0 meio extracelular e intracelular está praticamente intacta e com forma bem definida.
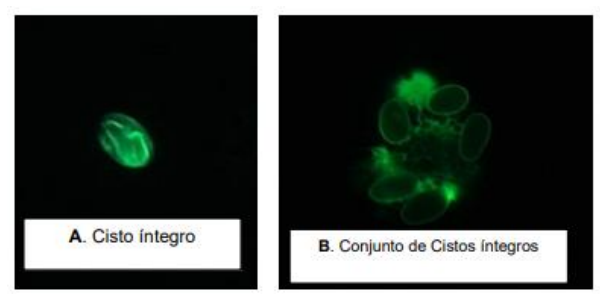

Figura 1. Imagens dos cistos microscópio de fluorescência.
Já a Figura $1 \mathrm{C}$ expõe uma alteração bastante visível desse formato, o que indica uma degradação celular causada pela exposição do microrganismo ao UV-LED. Também foi avaliada a eficiência percentual (relação entre a quantidade de cistos danificados e o total inoculado) de inativação dos agentes desinfetantes. A Tabela 1 mostra o comparativo entre o ensaio, realizado em triplicata, que avaliou a eficiência na inativação dos cistos de giárdia spp entre o UV-LED e o POA $\left(\mathrm{H}_{2} \mathrm{O}_{2}+\right.$ UV-LED). As amostras foram expostas a concentrações de $15 \mathrm{mg} / \mathrm{L}$ de $\mathrm{H}_{2} \mathrm{O}_{2}$ e 15 minutos da combinação entre os comprimentos de onda 255, 280, 365 e $405 \mathrm{~nm}$.

Tabela 1. Resultados do ensaio de eficiência dos agentes desinfetantes.

\begin{tabular}{cc}
\hline Tratamento & Cistos inativos (\%) \pm Des. Pad. (\%) \\
\hline POA & $79 \pm 0.2$ \\
UV-LED & $64 \pm 0.1$ \\
\hline
\end{tabular}

É possível perceber que o POA apresentou na média percentual os maiores valores de eficiência, ou seja, a combinação entre $\circ \mathrm{H}_{2} \mathrm{O}_{2}$ e $\circ$ UV-LED mostrou possuir maior poder desinfetante quando comparada a aplicação isolada da radiação ultravioleta.

\section{Conclusões}

De modo geral, constatou-se que a ação da radiação UV acontece sobre o nível cromossômico, atingindo e danificando a parede celular do microrganismo. Ademais, destaca-se o fato de que a combinação de dois agentes desinfetantes, $\mathrm{H}_{2} \mathrm{O}_{2}$ com UV-LED, implicou em melhores resultados de desinfecção quando comparado a atuação isolada de apenas um deles.

\section{Agradecimentos}

Agradeço especialmente a Jerusa Schneider e a Lays Leonel por todo o aporte intelectual durante os meses de pesquisa, vitais para a conclusão do projeto. Destaco o apoio do SAE no fomento à produção de conhecimento científico tão importante para o país.

${ }^{1}$ MELO, Silene Alessandra Santos et al. Degradação de fármacos residuais por processos oxidativos avançados. Quím. Nova, São Paulo, v. 32, n. 1, p. 188 197, 2009. 